\title{
Features of ultrasonic control of mechanical properties of core rocks of geological exploration wells
}

\author{
Anatolii Yalanskyi ${ }^{1, *}$ \\ ${ }^{1}$ Institute of Geotechnical Mechanics named by N. Poljakov of National Academy of Sciences of \\ Ukraine, 49005, Dnipro, Simferopolska Str., 2a, Ukraine
}

\begin{abstract}
The article discusses the features of ultrasonic operative control of the mechanical properties of rocks of geological exploration wells. The control develops in three directions: ultrasonic logging of exploration wells, the determination of the strength and elastic properties of rocks, taking into account their geological homogeneity; comprehensive monitoring of physical and mechanical properties of cores of deep and ultra-deep wells directly on the wells or core storage facilities. To control samples with untreated ends, it was proposed to use methods and means to ensure the point contact of the sensor with the surface, which allows to accurately determine the distance traveled by the waves through the sample, and taking into account the directional patterns of ultrasonic vibrations to determine the type and speed of the wave. According to the velocities of the longitudinal, shear or surface waves and the density of rocks determine the dynamic elastic parameters. The discrepancy between the actual structure of deep rock massif and seismic data is considered. With depth, the metamorphism of rocks increases. At the considered depths, the crust of rocks has a layered structure, which is due to the alternation of igneous and sedimentary rocks differing in the degree of metamorphism.
\end{abstract}

\section{Introduction}

The definition of physical and mechanical properties and stress-strain state of a massif of rocks is an important section of highly effective geological and geophysical monitoring, which is constantly evolving in both scientific and technical areas. As for relevance, then annually only in geological exploration organizations, in principle, it is possible to control millions of meters of core, but his choice, even in the coal industry, does not exceed $4 \%$ of the total. This selection is made only in rocks containing coal seams; therefore, much of the important information is irreversibly lost. In most cases, density, porosity, uniaxial compression and tensile strength, elastic moduli and Poisson's ratio, and gas content are determined. In addition, the structure and structure of rocks, the mineralogical composition and rheological characteristics are taken into account. This information fully satisfies the

*Corresponding author: yalanskiy.o.a@gmail.com 
designers, as expected, but it is not sufficient either in terms of volume or quality. Therefore, an improved ultrasonic control of the mechanical properties of rocks that are irreversibly destroyed during their extraction is important for solving technological problems, in particular ultra-deep drilling (predicting the properties of the bottom hole), and for obtaining objective primary geological and geophysical information. The determination of rock strength parameters is based on correlations with longitudinal wave velocities measured on samples and cores. Such an approach to determining strength is known, but the lack of classification of rocks by the degree of their genetic homogeneity does not give reliable predictions, and the need for mechanical processing of samples reduces the amount of measurements. As a basis for determining the elastic parameters of rocks and concrete, ultrasonic measurements of the propagation speeds of waves of various types on samples of arbitrary shape without prior mechanical treatment of their surface are proposed. Dynamic elastic parameters (Young's modulus and shear, Poisson's ratio and total compression modulus) are calculated using wave equations based on measured velocities of longitudinal and transverse (or surface) waves in the ultrasonic frequency range [1]. The aim of the work is to analyze the features of the method of ultrasonic control of the mechanical properties of rocks of geological exploration wells, including without their mechanical processing.

\section{Main job content}

\subsection{Physical-technical basis of the method and methodology of control}

To assess the accuracy of determining the strength of rocks under uniaxial compression, the most effective method of ultrasonic logging, taking into account the possibility of a complete transition of exploration to drilling without core sampling, was studied 45 wells. The place where the actual material was taken was located in the center of the study area. The detection efficiency of tectonic disturbances based on acoustic logging materials has been established. In this area, 46 violations were identified in 38 wells studied, 26 of which were confirmed by geological materials, mainly major violations. 20 tectonic disturbances with an amplitude of displacement of about $10 \mathrm{~m}$ were not established according to geological documentation, and 5 - according to acoustic logging data, without comprehensive analysis they would be omitted. In wells filled with a solution, the speed of propagation of elastic waves responds poorly to the destruction of rocks, therefore, the multiparameter control of an acoustic signal is rational: registration of exchange and reflected waves, amplitudes of longitudinal and transverse waves. Wave amplitudes sharply decrease with the appearance of individual cracks, more transverse waves than longitudinal ones, a further increase in fracture can no longer significantly reduce the signal amplitude, but in the crack zones the intensity of elastic waves decreases due to multiple reflections, which leads to a loss of phase line correlation. Repeated tests of core tectonic disturbance intervals by comparing the phase lines in acoustic logs confirmed the presence of cracks and cracks in the rocks. Disturbance of the phase line ratio also reveals rocks of a lumpy structure, which crumble into small, angular pieces as it dries. The intervals of lumps from tectonic cracks can be distinguished by reducing the speed of longitudinal waves. The average values of the propagation velocity of longitudinal waves according to acoustic logging data and compressive strength according to laboratory tests are presented in Table 1. Calculated systematic and random errors in determining the strength of rocks by acoustic logging and laboratory tests. Systematic differences in measurements depend on the magnitude of the effective stresses, the composition of the material, the compressive strength of the rocks, the structure and texture of the rocks; in accordance with the law of 
addition of errors, they do not exceed $\pm 15 \%$. Systematic errors can be reduced, taking into account additional factors, random reproduction errors using a number of measurements [2].

Table 1. Average values of the velocity of propagation of longitudinal waves $V p$ and tensile strength of rocks for uniaxial compression $\sigma_{\mathrm{c}}$ according to acoustic well logs.

\begin{tabular}{|l|c|c|c|c|c|c|c|c|c|}
\hline $\begin{array}{c}\text { Depth of } \\
\text { occurrence, } \\
\mathrm{m}\end{array}$ & \multicolumn{3}{|c|}{ Argillite } & \multicolumn{3}{c|}{ Aleurolite } & \multicolumn{3}{c|}{ Sandstone } \\
\cline { 2 - 11 } & $\begin{array}{r}V p, \mathrm{~s} \\
\mathrm{~m}\end{array}$ & $\begin{array}{c}\sigma_{\mathrm{c}}, \\
\mathrm{MPa}\end{array}$ & $\begin{array}{c}\text { Power } \\
\text { of } \\
\text { plates, } \\
\mathrm{m}\end{array}$ & $\begin{array}{c}V p, \\
\mathrm{~m} / \mathrm{s}\end{array}$ & $\begin{array}{c}\sigma_{\mathrm{c},} \\
\mathrm{MPa}\end{array}$ & $\begin{array}{c}\text { Power } \\
\text { of } \\
\text { plates, } \\
\mathrm{m}\end{array}$ & $\begin{array}{c}V p, \\
\mathrm{~m} / \mathrm{s}\end{array}$ & $\begin{array}{c}\sigma_{\mathrm{c},} \\
\mathrm{MPa}\end{array}$ & $\begin{array}{c}\text { Power } \\
\text { of } \\
\text { plates, } \\
\mathrm{m}\end{array}$ \\
\hline $0-100$ & 3440 & 30.5 & 6 & 3960 & 50.5 & 50 & 4350 & 72.0 & 31 \\
\hline $101-200$ & 3450 & 31.0 & 66 & 3850 & 45.5 & 116 & 4470 & 81.0 & 95 \\
\hline $201-300$ & 3500 & 32.0 & 193 & 3790 & 43.0 & 363 & 4330 & 70.5 & 238 \\
\hline $301-400$ & 3500 & 32.0 & 163 & 3940 & 49.5 & 468 & 4330 & 70.5 & 283 \\
\hline $401-500$ & 3460 & 31.0 & 354 & 3990 & 52.0 & 324 & 4600 & 92.5 & 313 \\
\hline $501-600$ & 3540 & 34.0 & 203 & 3960 & 50.5 & 464 & 4580 & 90.5 & 327 \\
\hline $601-700$ & 3510 & 32.5 & 312 & 3950 & 50.0 & 438 & 4520 & 85.0 & 213 \\
\hline $701-800$ & 3600 & 35.5 & 201 & 4010 & 53.0 & 377 & 4600 & 92.5 & 115 \\
\hline $801-900$ & 3640 & 37.0 & 233 & 4010 & 53.0 & 276 & 4580 & 90.5 & 139 \\
\hline $901-1000$ & 3820 & 44.0 & 97 & 4100 & 57.5 & 89 & 4760 & 108.5 & 407 \\
\hline $1001-1100$ & 3700 & 39.0 & 87 & 4030 & 54.0 & 111 & 4740 & 106.0 & 181 \\
\hline $1101-1200$ & 3730 & 40.5 & 112 & 4200 & 63.0 & 135 & 4640 & 96.5 & 62 \\
\hline $1201-1300$ & 3700 & 39.0 & 74 & 4100 & 57.5 & 82 & 4500 & 83.0 & 17 \\
\hline $1301-1400$ & 3780 & 42.5 & 30 & 4280 & 67.0 & 66 & 4900 & 124.0 & 4 \\
\hline
\end{tabular}

Since the majority of testing of rocks is aimed at determining the strength of rocks, the focus was on the standardization of these particular methods. Measurements of acoustic parameters for a homogeneous sample with a coefficient of variation of 5-10\% should be carried out on 3-4 samples, reflecting the representativeness of the sample, and with a coefficient of variation of 10-15\% - on 6-8 samples. It should be noted that long-term storage of core samples is unacceptable. Their preservation in laboratory studies should be made in a "fresh" state, and measurements of rocks should be carried out immediately after the arrival of the core in the laboratory. Therefore, when studying host rocks, it is necessary to regulate the time of the beginning of research or conservation of core samples. The study of changes in acoustic and strength characteristics of Donbas carbon-bearing rocks shows that stabilization of the properties under consideration during the period of elastic effects occurs on aleurolites and mudstones, on average, within 5 hours, and in sandstones within 2 hours after the core has been dredged from the core pipe. Information obtained in the study of the core immediately after its excavation, in any case, will be ambiguous due to the different residence time in the core tube of different parts of the core. Therefore, it is recommended to measure data on samples or to preserve rock samples in the following approximate time intervals after their extraction from the core pipe: 5-10 hours argillite; 524 hours siltstone; 2-24 hours sandstones [3].

Genetic affiliation of carbon-bearing rocks is divided into enlarged polygenetic groups (EPG) and elementary polygenetic types (EPT). EPG is a set of rocks characterized by close hydrodynamic conditions of sedimentation and further transformation due to the overlap of processes of epigenesis and tectogenesis (polygenetic concept). The main diagnostic features of EPG are lithological affiliation, the type of stratification of the rock, the stage of epigenesis and the main group of facies sedimentation. The larger taxonomic classification units in coal basins are geotectonic zones corresponding to the adopted large 
structural-tectonic regionalization of basins by geological-genetic complexes in the rank of coal-bearing formations. EPG - justified by statistical studies of the strength and acoustic characteristics of the host rocks of Donbas. The taxonomic units of the smallest rank are the granulometric varieties of rocks of a specific facies affiliation - EPT. Genetic classification is the basis of the catalog of regression equations. Regression equations for EPG rocks should be used for rapid mass definitions. The regression equations for EPT of rocks are recommended when mining technical problems are solved, related to the stability of workings and the need to identify the details of the facial conditions of sedimentation of rocks.

Author's methods and measurement techniques make it easy to associate the results of research with the actual structure of the massif and its actual geomechanical state, if several times in certain periods of time measure the velocity of elastic waves directly at the well and take into account the sampling time in the well. Then, by analogy of building calibration dependencies for concrete hardening, we determine the primary parameters from graphs (or tables) approximated by equations of linear or exponential type. On the other hand, when drilling deep and ultra-deep wells, respectively, Kolskaya (depth reached 12,060 m), Kryvyi Rih (explored depth of 3,500 m) and Saatlinskaya (depth reached 8,500 m) a sharp discrepancy was established between the generally accepted geological interpretation of deep seismic boundaries and their reality nature. As a result, as is well known, on the site of the expected "basaltic layer" of the Kola well, Archean granite gneisses of volcanic rocks were found; In the Kryvyi Rih well, an Archean granitoid foundation was found at the site of the supposed immersion of the lower Proterozoic ferruginous quartzites and the layers enclosing them. The reason for this discrepancy is that the horizons fixed at different depths of the continental crust and zones of increase (or decrease) in the velocities of the longitudinal elastic waves reflect not so much the peculiarities of the material composition of the rocks, but the changes in their physical condition. It was found that the rock undergoes a technogenic decomposition during the ascent from a depth of more than $5 \mathrm{~km}$ due to decompression, leading to a distortion of the petrophysical characteristics. It has been proven that the widely practiced method of determining the velocities of longitudinal and transverse waves in samples saturated with water or other liquids usually leads to erroneous results. The greatest agreement with the logging data is achieved by adjusting the values of these velocities measured by the core in normal conditions, by introducing corrections for pressure and temperature using experimental data for the corresponding depths [4] Sharp inversions of the velocity of longitudinal waves in sections consisting of rocks similar in mineral and chemical composition, observed at depths of $3.5-9.5 \mathrm{~km}$, are due to the presence of horizons and zones with abnormally high porosity and fracturing. For comparison, the speed of elastic waves (lengthwise $V p$ and shear $V s$ ) and the elastic parameters of rocks (Poisson's ratio $v$, Young's modulus $E$ and shear modulus $G$ ) of the superdeep well of Kryvyi Rih, determined directly at the well, are presented in Table 2 .

Evaluation of the physical and mechanical properties of rocks occurring at great depths is important for understanding the patterns of formation of these properties and the stress fields of an intact massif. For this purpose, six rock samples taken from the SG-1 superdeep well (Saatli) were tested in Institute of Geotechnical Mechanics named by N. Poljakov of National Academy of Sciences of Ukraine (the depth of sampling is $6516-7752 \mathrm{~m}$ ). The test samples had a prismatic shape, their transverse dimensions ranged from $18 \mathrm{~mm}$ to $23 \mathrm{~mm}$ with a height of $20 \mathrm{~mm}$ to $30 \mathrm{~mm}$. Dynamic elastic characteristics were determined by the method of ultrasonic sounding in parallel and perpendicular to the bedding at a frequency of $150 \mathrm{kHz}$ (Table 3) [1]. Ultrasonic tests showed that for all samples, the speed of passage of elastic waves and dynamic elastic characteristics have rather large values. The anisotropy coefficient of the tested samples, with the exception of sample 5383 (anisotropy 
coefficient of 1.27), is slightly different from unity, its average value is 1.08 . This indicates the relative homogeneity of the elastic properties in two mutually perpendicular directions.

Table 2. Elastic properties of rocks of the Kryvyi Rih ultradeep borehole.

\begin{tabular}{|l|c|c|c|c|c|c|}
\hline \multicolumn{1}{|c|}{ Rocks } & Depth, $\mathrm{m}$ & $\begin{array}{c}V p, \\
\mathrm{~m} / \mathrm{s}\end{array}$ & $\begin{array}{c}V s, \\
\mathrm{~m} / \mathrm{s}\end{array}$ & $v$ & $\begin{array}{c}G \cdot 10^{-4}, \\
\mathrm{MPa}\end{array}$ & $\begin{array}{c}E \cdot 10^{-4} \\
\mathrm{MPa}\end{array}$ \\
\hline Metasiltstone & $962-966$ & 4980 & 1560 & 0.446 & 0.632 & 1.831 \\
\hline Metasandstone & $1030-1034$ & 5530 & 1890 & 0.434 & 0.928 & 2.682 \\
\hline Metaconglomerate & $1148-1150$ & 4190 & 1530 & 0.423 & 0.608 & 1.730 \\
\hline Metasandstone & $1167-1172$ & 5130 & 2130 & 0.396 & 1.180 & 3.290 \\
\hline Metasiltstone & $1309-1319$ & 4560 & 2140 & 0.357 & 1.191 & 3.232 \\
\hline Slate & $1462-1473$ & 5190 & 2400 & 0.365 & 1.498 & 4.089 \\
\hline Metasandstone & $1490-1501$ & 6280 & 1710 & 0.460 & 0.759 & 2.216 \\
\hline Slate & $1700-1705$ & 4400 & 1970 & 0.375 & 1.009 & 2.775 \\
\hline Metasiltstone & $1747-1749$ & 2460 & 1340 & 0.292 & 0.468 & 1.209 \\
\hline Slate & $1845-1848$ & 4900 & 1540 & 0.445 & 0.616 & 1.781 \\
\hline Quartzite & $1938-1941$ & 6870 & 3410 & 0.339 & 3.016 & 8.080 \\
\hline Slate & $1993-1996$ & 5660 & 3700 & 0.115 & 3.562 & 7.943 \\
\hline Slate & $2105-2109$ & 4970 & 2910 & 0.237 & 2.200 & 5.455 \\
\hline Meta-siltstone & $2120-2123$ & 6029 & 2680 & 0.378 & 1.867 & 5.145 \\
\hline Quartzite & $2270-2276$ & 5570 & 3260 & 0.237 & 2.756 & 6.817 \\
\hline Plagiogranite & $2368-2373$ & 4640 & 3020 & 0.143 & 2.371 & 5.421 \\
\hline Amphibolite & $2534-2536$ & 5000 & 2270 & 0.372 & 1.339 & 3.674 \\
\hline Plagiogranite & $2548-2590$ & 3530 & 1690 & 0.353 & 0.741 & 2.005 \\
\hline Blastocataclasite & $2630-2635$ & 2530 & 1160 & 0.368 & 0.351 & 0.960 \\
\hline Blastocataclasite & $2728-2735$ & 6090 & 2220 & 0.423 & 1.282 & 3.648 \\
\hline Blastocataclasite & $2879-2886$ & 4790 & 2620 & 0.283 & 1.784 & 4.577 \\
\hline
\end{tabular}

Table 3. Elastic characteristics of rocks of the Saatly ultradeep well.

\begin{tabular}{|c|c|c|c|c|c|c|c|c|c|}
\hline \multicolumn{4}{|c|}{$\begin{array}{l}\text { Passage speed } \\
\text { of elastic waves }\end{array}$} & \multicolumn{2}{|c|}{$\begin{array}{c}\text { Dynamic elastic } \\
\text { modulus }\end{array}$} & \multicolumn{2}{|c|}{$\begin{array}{c}\text { Dynamic } \\
\text { shear modulus }\end{array}$} & \multicolumn{2}{|c|}{$\begin{array}{c}\text { Dynamic } \\
\text { Poisson's ratio }\end{array}$} \\
\hline \multicolumn{2}{|c|}{ Longitudinal } & \multicolumn{2}{|c|}{ Transverse } & \multirow{2}{*}{$\begin{array}{l}E_{\mathrm{d} \perp \times} \\
10^{-2} \\
\mathrm{MPa}\end{array}$} & \multirow{2}{*}{$\begin{array}{c}E_{\mathrm{d} \| \times} \\
10^{-2} \\
\mathrm{MPa}\end{array}$} & \multirow{2}{*}{$\begin{array}{c}G_{\mathrm{d} \perp \times} \\
10^{-2} \\
\mathrm{MPa}\end{array}$} & \multirow{2}{*}{$\begin{array}{l}G_{\mathrm{d} \|} \times \\
10^{-2}, \\
\mathrm{MPa} \\
\end{array}$} & \multirow[b]{2}{*}{$v_{\mathrm{d}} \perp$} & \multirow[b]{2}{*}{$v_{\mathrm{d}} \|$} \\
\hline $\begin{array}{l}V_{p} \perp \\
\mathrm{m} / \mathrm{s}\end{array}$ & $\begin{array}{l}V_{p} \|, \\
\mathrm{m} / \mathrm{s}\end{array}$ & $\begin{array}{l}V_{s} \perp \\
\mathrm{m} / \mathrm{s}\end{array}$ & $\begin{array}{l}V_{s \|} \\
\mathrm{m} / \mathrm{s}\end{array}$ & & & & & & \\
\hline 4530 & 5060 & 2310 & 3090 & 437.5 & 703.0 & 165.7 & 292.9 & 0.32 & 0.20 \\
\hline 4660 & 5270 & 2730 & 2780 & 551.2 & 629.5 & 225.9 & 245.9 & 0.22 & 0.28 \\
\hline 4690 & 4590 & 2600 & 2580 & 515.5 & 523.5 & 2030 & 211.1 & 0.27 & 0.24 \\
\hline 4590 & 4580 & 2700 & 2950 & 522.9 & 576.1 & 212.6 & 252.7 & 0.23 & 0.14 \\
\hline 4710 & 4660 & 2640 & 2690 & 500.0 & 543.3 & 196.8 & 224.5 & 0.27 & 0.21 \\
\hline 4020 & 4300 & 2700 & 2700 & 429.3 & 463.4 & 198.7 & 198.0 & 0.17 & 0.17 \\
\hline 4530 & 4740 & 2610 & 2800 & 492.7 & 573.1 & 200.5 & 237.5 & 0.23 & 0.21 \\
\hline
\end{tabular}

\subsection{Control equipment}

Experimental and methodological work on ultrasonic logging of exploration wells was performed using the laboratory of acoustic logging LAC-1. Due to the large size, the downhole probe was replaced by a small-sized one, which was developed by VIRG. The probe diameter is $60 \mathrm{~mm}$, which allows it to be used for well testing of $76 \mathrm{~mm}$ and more. 
The probe used circular magnetostrictive emitters with a pronounced resonant frequency from 30 to $35 \mathrm{kHz}$. Emitters do not have energetically significant harmonics that can affect the results of field studies. The receivers of elastic vibrations were piezoceramic cylindrical transducers made of ceramics of the PZT-19 type. The distance between the receivers and the emitters is about $0 ; 5 ; 1$ and $2 \mathrm{~m}$. For the rapid determination of the elastic properties of the core with untreated ends and samples of arbitrary shape, methods and means of ultrasonic testing have been developed, which ensure rigid local contact of the sensors with their surface and make it possible in complex to determine the velocities of longitudinal and shear vibrations. There are several signs that make it possible to isolate a transverse wave from a common recorded signal: 1) by the propagation time; 2) by the ratio of the amplitudes; 3) by phase shift; 4) the difference in frequency. However, none of these signs separately provides reliable and stable selection of transverse waves [5]. The proposed use of emitters and receivers with concentrators, such as conical, the length of which is equal to an integer number of half-waves of ultrasonic vibrations in the material from which they are made, which is necessary to determine the vector directionality of ultrasonic vibrations and ensure reliable contact of sensors with a rough core or sample The accuracy of determining the distance traveled by the waves through the sample also increases. Such devices allow measurements with an accuracy of $\pm 0.5 \%$. The devices "Kernoskop- 1 " and "Kernoskop-2" were transferred to geological exploration expeditions for testing and implementation. The use of portable equipment such as "Kernoskop", UK-10PMS, UK$10 \mathrm{PM}$, as well as any other ultrasonic equipment, allows for rapid mass determination of the elastic and strength properties of various rocks, resulting in an increase in the amount of information about these properties, with a significant reduction in costs for rock testing and exploration in general.

\section{Conclusion}

Both the equipment and the measurement technology have been subjected to numerous tests, from factory, departmental and interdepartmental acceptance tests to state. Instruments and techniques for controlling elastic properties on samples of different rocks were tested: coarse-grained granites, homogeneous sandstones, sandstones with large irregular inclusions, layered sandstones, siltstone, mudstones, iron and phosphate ores, cores of ultradeep wells, composite materials as well as on highly porous rocks - cut limestone, shell rock, manganese nodules from the depths of the ocean above $6000 \mathrm{~m}$. On homogeneous rocks, the transverse wave is clear. On layered, porous and granular rocks less distinct, but the shear wave is determined on all samples without exception. By the quality of the oscillograms, the methods are equivalent to the immersion method. Their undeniable advantage is high performance by bringing measurements to almost automatic results. Over wells, rock metamorphism increases with depth. The crystalline crust up to the considered depths has a differentially layered structure due to the alternation of igneous and sedimentary rocks metamorphosed to various degrees.

The results are part of the program "Promoting the development of priority research areas" (KPKVK 6541230) of state funding for the National Academy of Sciences of Ukraine.

\section{References}

1. Usachenko, B.M., Yalansky, A.A., Palamarchuk, T.A., Bobro, N.T., Yarovaya, T.I. (2010). Osobennosty yzuchenyia heolohycheskoho stroenyia y heomekhanycheskoho 
sostoianyia massyva hornykh porod skvazhynamy sverkhhlubokoho burenyia. Materials of the International Conference "Forum of the Civilists - 2010" (3), 35 - 43

2. Glushko, V.T., Kusch, A.M., Kucheba, P.K., Khlystov, V.I., Yalansky, A.A. (1974). Ultrazvuk v razvedochnom burenyy. Donetsk: Donbas

3. Mayboroda, A.A., Minyafayev, R.Kh., Alferov, O.S., Yalansky, A.A. (1988). Rukovodstvo po ekspress-opredelenyiu prochnostnykh svoistv uhlevmeshchaiushchykh porod Donbassa po ykh heolohycheskym kharakterystykam y akustycheskym yzmerenyiam kernov heolohorazvedochnykh skvazhyn. Dnipropetrovsk: DGI. Part I. 48, Part II. - 82

4. Nalivkina, E.B, Ostroumova, A.S., Suslova, S.N. (1988). Hlubynnoe stroenye kontynentalnoi kory po Kolskoi, Kryvorozhskoi, Uralskoi, Muruntauskoi, Saatlynskoi sverkhhlubokym skvazhynam. Sverkhhlubokoe kontynentalnoe burenye y hlubynnye heofyzycheskye yssledovanyia. Yaroslavl: MinGEO USSR

5. Yalansky, A.A., Palamarchuk, T.A., Skipochka, S.I. (1987). Vremennye metodycheskye ukazanyia po opredelenyiu upruhykh svoistv hornykh porod ultrazvukovym metodom na neobrabotannykh obraztsakh kerna heolohorazvedochnykh skvazhyn. Leningrad: VNIMI 